\title{
MODELLING OF THE STRATEGIC PLANNING PROCESS AT AN AGRICULTURAL ENTERPRISE
}

\author{
IRYNA BORYSHKEVYCH, ALEKSANDER IWASZCZUK
}

\begin{abstract}
The development strategy is a long-term roadmap of the company's activities, which makes it possible to achieve higher performance in relation to competitors. Almost all managers of agricultural enterprises in the process of strategic management face a number of problems, such as the choice of appropriate tools for strategic analysis and methods for building a strategy. This is based on the fact that different agricultural enterprises have different existing capabilities, available resources and strategic planning needs. Depending on the strategic ability of agricultural enterprises, it is proposed to use various tools of strategic analysis and methods of strategy development. Based on the conducted research, there was formed a mechanism for implementing strategic planning at an agricultural enterprise. It consists of three stages. The developed mechanism was tested at a private agricultural enterprise 'Ridna Zemlia' (Native Land) with the typical main indicators of economic activity in the Ivano-Frankivsk region. At the first stage, using a balanced system of economic indicators, it was found that this enterprise has an average level of strategic ability. Following the recommended strategic analysis tools, at the second stage of strategic planning, SWOT analysis of an agricultural enterprise was conducted identifying its strengths and weaknesses, existing opportunities and threats. At the third stage, a roadmap for implementing the strategy was developed within the framework of using the road mapping method, which is allowed by the appropriate level of strategic capability. The main strategic goal of the developed strategy is to ensure sustainable profits in the long term by increasing the productivity and efficiency of agricultural production. Based on this, the following strategic tasks were proposed to implement: the introduction of a new technology, which consists of constant monitoring of the herd of cows, opening of a new farm to expand the existing market and increase production volumes, the construction of a pellet boiler farm using biofuels, as well as the formation of a personnel training plan and the development and implementation of training programs for employee development.
\end{abstract}

Keywords: strategy, method, agricultural enterprise, strategic planning, roadmap.

JEL Classification: A11, D23, M10.

\section{INTRODUCTION}

In the modern business environment, the management of most agricultural enterprises begins to realize the need for strategic planning, formation and implementation of further development strategies and tries to use the existing methodological tools in their activities. At the same time, the process of strategic planning has not found a systematic reflection in practice. The vast majority of 
agricultural enterprises carry out strategic planning chaotically without having a clear developed model and effective mechanism. In addition, different agricultural enterprises have different available opportunities and resources to analyse and develop a development strategy. That is why it is important to form a clear mechanism for implementing strategic planning with an indication of specific stages and test the results received at one of the agricultural enterprises.

\section{THEORETICAL BACKGROUND}

A strategy is one of the most important concepts of the modern age [1], which determines the effectiveness of achieving the company's goals [2]. Strategic planning is a deliberate and disciplined effort aimed at making fundamental decisions and actions that determine what an organization is, what it does, and why [3]. Strategic planning is an analysis that involves dividing the goals set into steps that are manageable and implemented in order to achieve the desired aim [4]. Thus, strategic planning is a process that outlines the goals and objectives of the enterprise, formulates actions and allocates resources that will be used to achieve the set goals.

The problems and prospects of using strategic planning in the activities of agricultural enterprises are studied by scientists from different countries, in particular: J. Jaworski, K. Sokołowska, T. Kondraszuk [5], J. Dyczkowska, T. Dyczkowski [6] (Poland), H. Chladkova, S. Formankova [7] (the Czech Republic), J. Schindler, F. Graef, H. König [8] (Germany), C.-C. Chen, H.-P. Yueh, C. Liang [9] (China), S. Suriyankietkaew, P. Petison [10] (Thailand), R. Kalaki, M. Neves [11] (Brazil). Taking into account the peculiarities of the development of agricultural enterprises, scientists offer various ways to solve existing problems. However, most of them focus on the fact that strategic management is important for the successful development of the agricultural sector.

Studying the strategic directions of agricultural enterprises development scientists use various tools of strategic analysis and methods of building strategies: PEST analysis [12; 13], PESTEL analysis [14], SWOT analysis [15-17], roadmap method [18; 19], Hoshin Kanri method [20].

Summarizing the available scientific research in the field of strategic planning for the development of agricultural enterprises, we come to conclusion that modern agribusiness requires strategic thinking among enterprise managers, which results in the formation of a clear development strategy. The use of various tools of strategic analysis and methods of building a strategy will ensure the development of a strategic plan according to the capabilities of the enterprise. The development strategy of an agricultural enterprise makes it possible to clearly define the goals, ensures the readiness of the enterprise for changes in unstable external conditions and allows to gain competitive advantages in the market.

\section{Research Objective, Methodology and Data}

The purpose of this article is to model the process of strategic planning at an agricultural enterprise and develop a strategy for its further development. Having a developed strategy makes it possible to achieve clearly defined goals, which include improving the availability of the enterprise resources, expanding partnerships, improving the management system, rising the number of consumers, which ultimately increases the profitability and financial independence of the enterprise. Strategic planning at an agricultural enterprise involves implementation of three main stages (Fig. 1). 
Stage 1. Determine the strategic capacity of an agricultural enterprise by using a balanced system of economic indicators

Stage 2. Conduct strategic analysis using tools based on the level of strategic capacity

Stage 3. Build the strategy of an agricultural enterprise using a method that corresponds to the level of strategic capacity of an agricultural enterprise

Fig.1. Implementation stages of strategic planning at an agricultural enterprise. Source: author's development.

At the first stage, it is necessary to establish the level of strategic ability of an agricultural enterprise using a balanced system of economic indicators, based on their economic efficiency. This system is based on calculating the land usage, financial, labour, material and technical resources utilized by an agricultural enterprise. Having defined the integral group indicator for each direction of the economic indicators in the balanced system, we can build a line diagram that will allow us to visually represent and compare the rate of resources utilization. This, in turn, will make it possible to improve the activities of those areas where the situation is the worst. The next step of this stage is to calculate the overall integral indicator, which determines the level of strategic ability of an agricultural enterprise (Table 1).

\begin{tabular}{|l|l|}
\hline $\begin{array}{c}\text { Overall value of integral indicator in } \\
\text { the balanced system of economic } \\
\text { indicators }\end{array}$ & \multicolumn{1}{c|}{ Type of agricultural enterprise } \\
\hline from 0 to 0,35 & Enterprises with a low level of strategic capacity \\
\hline from 0,36 to 0,70 & Enterprises with an average level of strategic capacity \\
\hline from 0,71 to 1 & Enterprises with a high level of strategic capacity \\
\hline
\end{tabular}

Tab. 1. Scale for evaluating the strategic capacity of agricultural enterprises. Source: [21].

At the second stage, we should carry out a strategic analysis, and at the third stage, we should build a strategy using appropriate tools and methods, which are based on the level of strategic capability of agricultural enterprises (Table 2).

\begin{tabular}{|c|c|c|}
\hline Type of agricultural enterprises & Strategic analysis tools & $\begin{array}{c}\text { Methods for building a } \\
\text { strategy }\end{array}$ \\
\hline $\begin{array}{c}\text { Enterprises with a low level of } \\
\text { strategic capacity }\end{array}$ & SWOT analysis & Objectives Tree method \\
\hline $\begin{array}{c}\text { Enterprises with an average } \\
\text { level of strategic capacity }\end{array}$ & $\begin{array}{c}\text { PEST analysis, SWOT analysis, } \\
\text { Ansoff Matrix, Porter's Five } \\
\text { Forces analysis, creating } \\
\text { strategic groups map }\end{array}$ & $\begin{array}{c}\text { Roadmapping } \\
\text { (building a roadmap), } \\
\text { Balanced Scorecard method }\end{array}$ \\
\hline $\begin{array}{c}\text { Enterprises with a high level of } \\
\text { strategic capacity }\end{array}$ & $\begin{array}{c}\text { TELESCOPIC } \\
\text { OBSERVATIONS, ADL model, } \\
\text { McKinsey Matrix }\end{array}$ & Hoshin Kanri method \\
\hline
\end{tabular}

Tab. 2 Classification of strategic analysis tools and building strategy methods depending on the strategic capability of an agricultural enterprise. Source: [21]. 
Having a developed strategy makes it possible to achieve clearly defined goals, including improving the resource availability of the enterprise, expanding partnerships, improving the management system, rising the number of consumers, which ultimately increases the profitability and financial independence of the enterprise.

\section{RESULTS AND DISCUSSION}

The developed strategic planning mechanism was tested at a private agricultural enterprise 'Ridna Zemlia' (Native Land) specializing in the cultivation of grain crops (except rice), legumes and oilseeds. This enterprise is typical in terms of the main indicators of economic activity in the Ivano-Frankivsk region.

At the first stage of strategic planning, we determined the level of strategic capacity of the agricultural enterprise using a balanced system of economic indicators. Calculations were made on the basis of the financial report of the 'Ridna Zemlia' (Native Land) enterprise.

The results of calculations of the economic indicators balanced system are shown in Table 3.

\begin{tabular}{|c|l|l|l|}
\hline \multirow{2}{*}{ Direction } & \multicolumn{2}{|c|}{ Indicator name } & \multicolumn{2}{c|}{ Indicator value } \\
\cline { 3 - 4 } & & \multicolumn{1}{c|}{ Normative } & \multicolumn{1}{c|}{ Calculated } \\
\hline \multirow{4}{*}{$\begin{array}{c}\text { Use of land resources } \\
\text { land }\end{array}$} & $\begin{array}{l}\text { Gross output production per 100 ha of } \\
\text { growth }\end{array}$ & 0,3125 \\
\hline \multirow{4}{*}{$\begin{array}{c}\text { Use of financial } \\
\text { resources }\end{array}$} & Total liquidity ratio & more than 0,1 & 0,0198 \\
\cline { 2 - 4 } & Long-term debt ratio & more than 1 & 2,7502 \\
\cline { 2 - 4 } & Return on equity (ROE) & less than 1 & 1,5179 \\
\cline { 2 - 4 } & Return on assets (ROA) & $1 \%$ & $13,8139 \%$ \\
\hline \multirow{2}{*}{$\begin{array}{c}\text { Use of labour } \\
\text { resources }\end{array}$} & Productivity factor & $\begin{array}{l}\text { most suitable } \\
10-20 \%\end{array}$ & $5,1208 \%$ \\
\cline { 2 - 4 } & Return on learning (ROL) & growth & 0,8921 \\
\cline { 2 - 4 } & Turnover rate of personnel & growth & 0,4846 \\
\hline \multirow{2}{*}{$\begin{array}{c}\text { Use of material and } \\
\text { technical resources }\end{array}$} & Current asset turnover ratio & reduction & 0,1 \\
\cline { 2 - 4 } & Inventory turnover ratio & growth & 0,9341 \\
\cline { 2 - 4 } & Inventory return ratio & growth & 1,9057 \\
\hline
\end{tabular}

Tab. 3 Private agricultural enterprise 'Ridna Zemlia' analysis results based

on the economic indicators balanced system. Source: author's research.

In the next step, we calculated integral resource efficiency indicators, taking into account the weight of the impact of each group of indicators.

Since the influence of the land-use efficiency on the development of the agricultural enterprise is 0.365 , the land-use efficiency integral indicator is:

Land-use efficiency integral indicator $=0,3125 \times 0,365=0,1141$.

The influence of the financial resources efficiency use is 0.2. thus, the integral indicator of the efficiency of financial resources use is as follows:

Financial resources use efficiency integral indicator $=$

$$
\sqrt[5]{0,0198 \times 2,7502 \times 1 / 1,5179 \times 13,8139 \% \times 5,1208 \%} \times 0,2=0,0381 .
$$


The influence of the labour resource efficiency is 0.225 . The integral indicator of labour resource efficiency is equal to:

Labour resource use efficiency indicator $=\sqrt[3]{0,8921 \times 0,4846 \times 1 / 0,1} \times 0,225=0,3665$.

Since the influence of the efficiency of material and technical resources use on the development of an agricultural enterprise is 0.21 , the integral indicator of the use of material and technical resources is:

Material and technical resources use integral indicator $=\sqrt[3]{0,9341 \times 1,9057 \times 0,1568} \times 0,21=0,1372$.

Based on the results of the obtained integral indicators of resource utilization, we constructed the integrated values line diagram of the components of the economic indicators balanced system (Fig. 2).

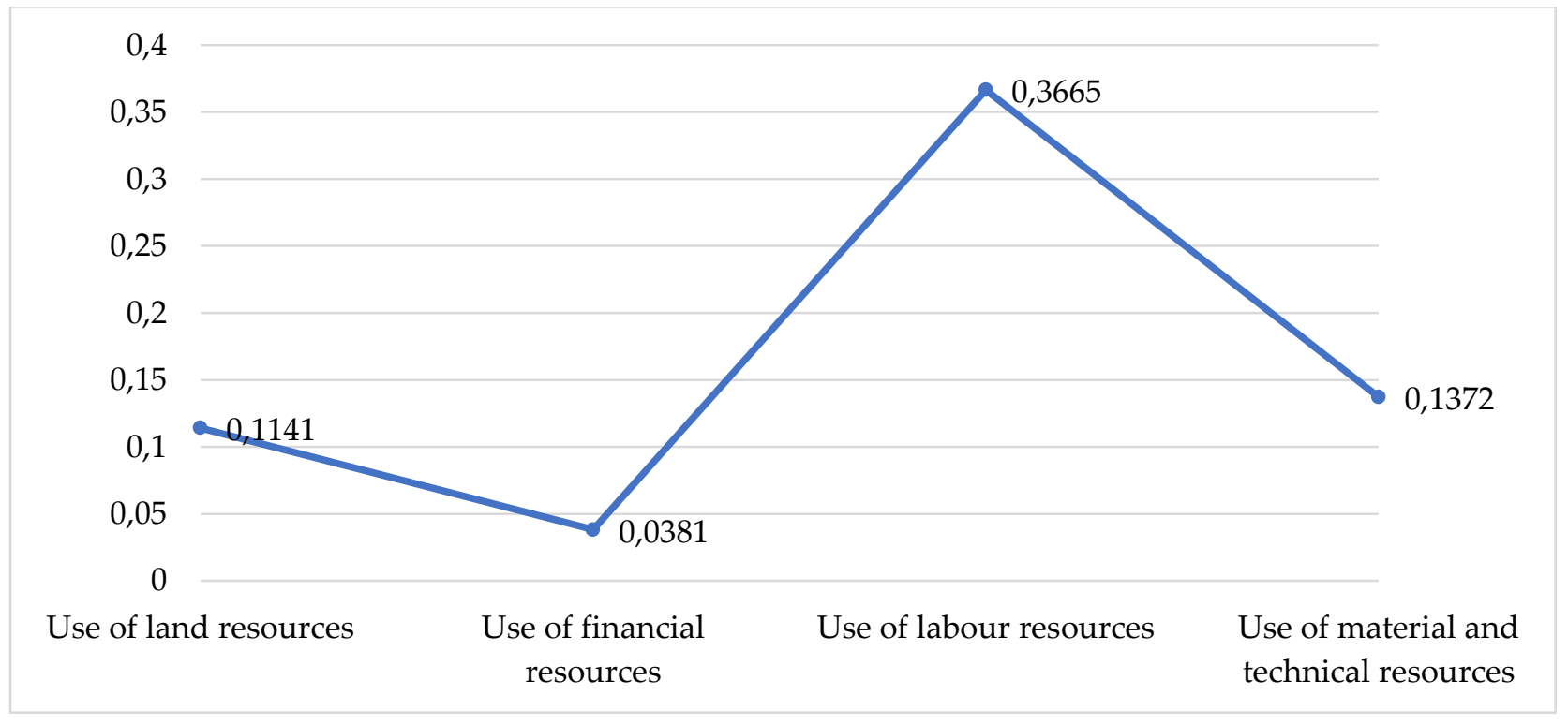

Fig. 2. Integrated values of the components of the economic indicators balanced system at agricultural enterprise 'Ridna Zemlia. Source: authors research.

Based on the results of the constructed diagram, we can conclude that the level of labour resources utilization on the private agricultural enterprise 'Ridna Zemlia' is positive, which is 0.3665 . The level of land, material and technical resources utilization is almost the same, their integrated values are 0.1141 and 0.1372 , accordingly. The utilization of financial resources is in the worst position, the size of the integral group indicator is 0.0381. In order to determine the level of strategic capability of an agricultural enterprise we calculated the overall integral indicator of the economic indicators balanced system:

Overall integral indicator $=0,1141+0,0381+0,3665+0,1372=0,6559$.

The calculated general integral indicator of the studied enterprise falls in the range from 0.36 to 0.70. This allows us to conclude that the agricultural enterprise 'Ridna Zemlia' belongs to the list of enterprises with an average level of strategic capability.

SWOT analysis of the 'Ridna Zemlia' agricultural enterprise is indicated in Tab. 4. 


\begin{tabular}{|c|c|}
\hline Strengths & Weaknesses \\
\hline $\begin{array}{l}\text { 1. Solid experience in the agricultural sector. } \\
\text { 2. Production of exclusively natural dairy products. } \\
\text { 3. Milk processing exclusively from their own } \\
\text { farms. } \\
\text { 4. The largest number of cattle in the Ivano } \\
\text { Frankivsk region. } \\
\text { 5. Wide range of products. } \\
\text { 6. Use of modern foreign equipment. } \\
\text { 7. High-tech modern production. } \\
\text { 8. Highly qualified employees. } \\
\text { 9. High-quality products, compliance with } \\
\text { Ukrainian and European quality standards. } \\
\text { 10. High social responsibility. }\end{array}$ & $\begin{array}{l}\text { 1. Dependence of an agricultural enterprise on } \\
\text { weather conditions. } \\
\text { 2. Short storage time of fermented milk products. } \\
\text { 3. Sales of dairy products only in those regions that } \\
\text { are geographically close to production facilities. } \\
\text { 4. High level of competition. } \\
\text { 5. Non-perfect marketing policy. } \\
\text { 6. Incomplete implementation of strategic planning } \\
\text { and lack of a clearly developed strategy. }\end{array}$ \\
\hline Opportunities & Threats \\
\hline $\begin{array}{l}\text { 1. Expansion of the products sold volume. } \\
\text { 2. Expansion of the product range. } \\
\text { 3. Increase in new production capacity points (new } \\
\text { farms). } \\
\text { 4. New sales markets entrance. } \\
\text { 5. Attracting new investors. } \\
\text { 6. Reducing the cost of production. } \\
\text { 7. Creation and implementation of an effective } \\
\text { development strategy. }\end{array}$ & $\begin{array}{l}\text { 1. Escalation of the military situation in the country. } \\
\text { 2. Poor weather conditions (drought, freezing of } \\
\text { crops, etc.). } \\
\text { 3. Emerging competitors (in particular foreign } \\
\text { ones). } \\
\text { 4. Price increase for agricultural machinery, energy } \\
\text { resources, fertilizers. } \\
\text { 5. Price increases due to inflation. } \\
\text { 6. Reducing consumer demand. } \\
\text { 7. Processes of stagnation in the Ukrainian } \\
\text { economy. } \\
\text { 8. Deterioration of credit conditions (increased } \\
\text { interest rates, inefficient credit conditions). }\end{array}$ \\
\hline
\end{tabular}

Tab. 4 SWOT analysis of the 'Ridna Zemlia' agricultural enterprise. Source: author's research.

Based on the SWOT analysis results, it is recommended to form a strategic vision in the innovative direction for this agricultural enterprise, that is, to continue improving existing technologies and introduce new ones. This will make it possible to ensure a stable profit in the Ukrainian market, as well as to enter international markets.

After conducting strategic analysis, the third important stage in the implementation of strategic planning at an agricultural enterprise is the construction of a strategy. Since the private agricultural enterprise 'Ridna Zemlia' is an enterprise with an average level of strategic ability, we used the road mapping method, to develop the strategy. An important advantage of this method is that it defines the relationships between different divisions and areas of the enterprise. In addition, the basis of road mapping is the use of new modern technologies and innovations.

Using the above-described method, we formed a roadmap to implement the strategy of the 'Ridna Zemlia' agricultural enterprise (Fig. 3). 


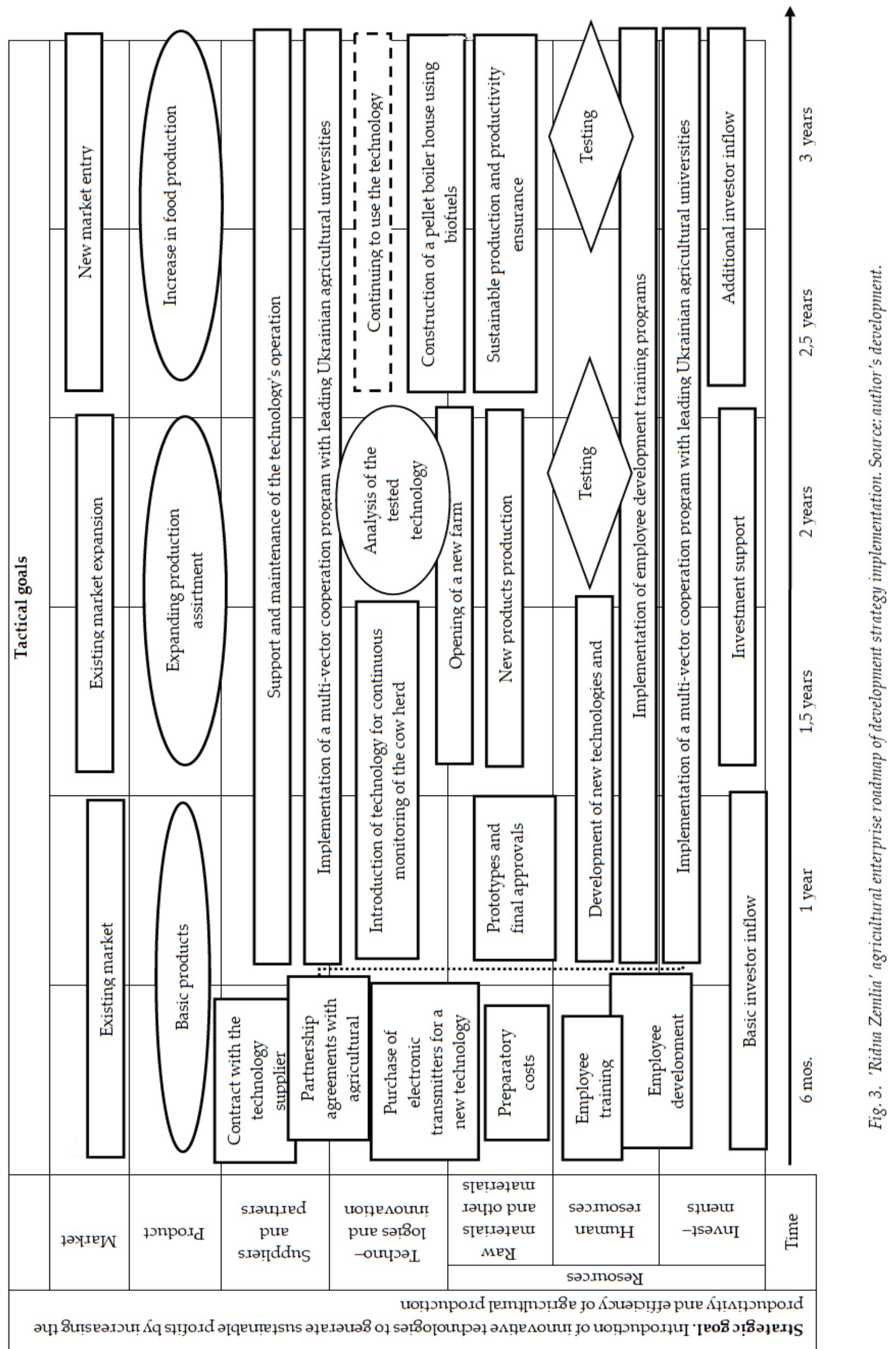


As you can see from Fig. 3, the main strategic goal for the 'Ridna Zemlia' agricultural enterprise is to introduce innovative technologies to generate sustainable profits by increasing the productivity and efficiency of agricultural production. Thus, it is suggested to introduce a new technology, which consists of constant monitoring of the cows' herd. This technology makes it possible to detect the slightest deviations in the state of their health. It is implemented using a personal electronic transmitter attached to the collar of each cow. With its help, the information about the animal (physiological parameters, cow activity, feeding quality) is collected during the day and transmitted to the central computer. This technology is used by one of the most successful agricultural companies in Ukraine, Svarog West Group Corporation. To implement this technology at the initial stage, you need to sign an agreement with the technology supplier. After a year of usage, analyse the proven technology and decide on its further utilization.

It is also planned to open a new farm to expand the existing market and increase production volumes. Using additional investor inflows, within the developed strategy it is possible to construct of a pellet boiler house using biofuels - fuel pellets. This is an important area of alternative energy development, which will allow us to cover our own energy needs.

An important aspect of implementing the strategy and ensuring the effective operation of the private agricultural enterprise 'Ridna Zemlia' is personnel training. After all, investing in human capital is one of the main factors of success in the long term. The current strategy provides for the formation of a staff training plan and the development and implementation of employee development training programs. At the end of each annual course, employees will test their knowledge. It is also proposed to conclude strategic partnership agreements with leading Ukrainian agricultural universities. The main goal of such cooperation is to strengthen the theoretical base with knowledge of modern technologies, as well as train the best students with subsequent employment.

In general, the developed roadmap for strategic planning implementation of the private agricultural enterprise 'Ridna Zemlia' should ensure a sustainable profit in the long term.

\section{CONCLUSIONS}

In conclusion, using a balanced system of economic indicators, it was established that the private agricultural enterprise 'Ridna Zemlia' has an average level of strategic ability. Based on the conducted SWOT analysis and available information about the company, a roadmap for strategic planning implementation was built. It is based on the introduction of innovative technologies to obtain sustainable profits in the long term. In addition, the use of roadmaps at the enterprise makes it possible to achieve key strategic and tactical goals. They help to focus on long-term planning and improve relationships, provide comprehensive, visual, and autonomous plans. This method focuses business leaders thinking on key tasks at each stage of strategic planning.

\section{REFERENCES}

[1] Carter C. The age of strategy: strategy, organizations and society. Business History, 55 (7) (2013), 10471057. doi: 10.1080/00076791.2013.838030

[2] Fuertes G., Alfaro M., Vargas M., Gutierrez S., Ternero R., Sabattin J. Conceptual Framework for the Strategic Management: A Literature Review - Descriptive. Journal of Engineering, 2020 (2020). doi: $10.1155 / 2020 / 6253013$

[3] Bryson J.M., Edwards L.H., Van Slyke D.M. Getting strategic about strategic planning research. Public Management Review, 20 (3), (2018), 317-339. doi: 10.1080/14719037.2017.1285111 
[4] Babandi I. The Impact of Strategic Planning on Growth of Small Businesses in Nigeria. SEISENSE Journal of Management, 2 (1), (2019) 69-84. doi:10.33215/sjom.v2i1.85

[5] Jaworski J., Sokołowska K., Kondraszuk T. Sources of Strategic Information in Farm Management in Poland. Study Results. Journal of Management and Business Administration. Central Europe, 25 (1) (2017), 98-120. doi: 10.7206/jmba.ce.2450-7814.191

[6] Dyczkowska J., Dyczkowski T. An Influence of Strategic Awareness on Management Control: Evidence from Polish Micro, Small and Medium-sized Enterprises. Management and Business Administration. Central Europe, 23 (1) (2015), 3-31. doi: 10.7206/mba.ce.2084-3356.131

[7] Chladkova H., Formankova S. Strategy for SMEs in the area of primary agricultural production. Agricultural Economics, 62 (9) (2016), 395-406. doi: 10.17221/260/2015-AGRICECON

[8] Schindler J., Graef F., König, H. J. Methods to assess farming sustainability in developing countries. A review. Agronomy for Sustainable Development, 35 (2015), 1043-1057. doi: 10.1007/s13593-015-0305-2

[9] Chen C.-C., Yueh H.-P., Liang C. Strategic management of agribusiness: Determinants and trends. Journal of Entrepreneurship, Management and Innovation, 12 (4), (2016). doi: 10.7341/20161244

[10] Suriyankietkaew S., Petison P. A Retrospective and Foresight: Bibliometric Review of International Research on Strategic Management for Sustainability, 1991-2019. Sustainability, 12 (1) (2019). doi: 10.3390/su12010091

[11] Kalaki R.B., Neves M.F. Strategic plan for the Brazilian agro-industrial citrus system. Gestão \& Produção, 24 (2) (2017), 338-354. doi: 10.1590/0104-530x1307-15

[12] Yakubiv V., Boryshkevych I., Piatnychuk I., Iwaszczuk N., Iwaszczuk A. Strategy for the Development of Bioenergy Based on Agriculture: Case for Ukraine. International Journal of Renewable Energy Research, 10 (3) (2020), 1092-1102. Available at: https://www.ijrer.org/ijrer/index.php/ijrer/article/view/10867/pdf

[13] Yakubiv V., Boryshkevych I. Strategic Analysis of the Development of Renewable Energetics in the World and in Ukraine. Journal of Vasyl Stefanyk Precarpathian National University, 5 (3-4) (2018), 33-43. doi: 10.15330/jpnu.5.3-4.33-43

[14] Ziouta A., Azaba A. Industrial Product Service System: A Case Study from the Agriculture Sector. Procedia CIRP, 33 (2015), 64-69. doi: 10.1016/j.procir.2015.06.013

[15] Boryshkevych I., Yakubiv V. The Mechanism of Formation and Implementation of the Strategy of Development of Agricultural Enterprises. Vasyl Stefanyk Precarpathian National University Publishing House, IvanoFrankivsk, 2020. (in Ukrainian)

[16] Valverde A., Magalhães-Fraga S., Magalhães J., Barroso W. Agrobiodiversity Products by SWOT Analysis as an Analysis for Strategic Innovation. Journal of Technology Management \& Innovation, 10 (4) (2015), 57-63. doi: 10.4067/S0718-27242015000400006

[17] Regmi S., Naharki K. A SWOT Analysis of Agribusiness Entrepreneurship in Nepal. Food $\mathcal{E}$ Agribusiness Management, 1 (2) (2020), 60-65. doi: 10.26480/fabm.02.2020.60.65

[18] Arafat M.Y., Saleem I., Dwivedi A.K. et al. Determinants of agricultural entrepreneurship: a GEM data based study. International Entrepreneurship and Management Journal, 16 (2020), 345-370. doi: 10.1007/s11365-018-0536-1

[19] Zhao Q., Huang J. Roadmap of Agricultural Modernization and Intelligentization Science and Technology Development. In: Zhao Q., Huang J. (Eds) Agricultural Science \& Technology in China: A Roadmap to 2050. Springer, Berlin, Heidelberg, 2011. doi: 10.1007/978-3-642-19128-2_8

[20] Boryshkevych I. Formulation of a Typical Development Strategy for Agricultural Enterprises (by the Method of Hoshin Kanri). Journal of Vasyl Stefanyk Precarpathian National University, 6 (3-4) (2019), 15-21. doi: 10.15330/jpnu.6.3-4.15-21

[21] Yakubiv V., Boryshkevych I., Yakubiv R., Balanced System of Economic Performances as a Strategyforming Tool of Development of Agricultural Enterprises. Scientific Papers Series "Management, Economic Engineering in Agriculture and Rural Development", 19 (3) (2019), 669-679. 
Address: Iryna Boryshkevych, Vasyl Stefanyk Precarpathian National University, 57 Shevchenko St., IvanoFrankivsk, 76016 Ukraine;

Aleksander Iwaszczuk, Cracow University of Technology, 24 Warszawska St., Krakow, 31-155

Poland.

E-mail: ira.boryshkevych@gmail.com, aleksander.iwaszczuk@gmail.com

Received: October 25, 2020; revised: November 15, 2020.

Боришкевич Ірина, Іващук Олександр. Моделювання процесу стратегічного планування на сільськогосподарському підприємстві. Журнал Прикарпатського університету імені Василя Стефаника, 7 (3) (2020), 137-146.

Стратегія розвитку є довгостроковою дорожньою картою діяльності підприємства, що дає можливість досягнути більш високих показників по відношенню до конкурентів. Практично всі керівники сільськогосподарських підприємств в процесі стратегічного управління стикаються 3 низкою проблем, таких як, вибір доцільних інструментів для стратегічного аналізу та методів побудови стратегії. Це виходить із того, що різні сільськогосподарські підприемства мають різні існуючі мождивості, наявні ресурси та потреби в стратегічному плануванні. В залежності від стратегічної спроможності сільськогосподарських підприємств, запропоновано використовувати різні інструменти стратегічного аналізу та методи розробки стратегії. На основі проведених досліджень було сформовано механізм здійснення стратегічного планування на сільськогосподарському підприємстві, який скдадається з трьох етапів. Розроблений механізм апробовано на приватному сільськогосподарському підприємстві “Рідна земля", що є типовим за основними показниками господарської діяльності в Івано-Франківській області. На першому етапі, використовуючи збалансовану систему економічних показників, було встановлено, що дане підприємство має середній рівень стратегічної спроможності. Відповідно до рекомендованих інструментів стратегічного аналізу на другому етапі стратегічного планування автором було проведено SWOT-аналіз сільськогосподарського підприємства та виявлено його сильні і слабкі сторони, існуючі мождивості і загрози. На третьому етапі було розроблено дорожню карту реалізації стратегії в межах використання методу роудмеппінг, що передбачений відповідним рівнем стратегічної спроможності. Основною стратегічною метою розробленої стратегії $е$ забезпечення стійкого прибутку в довгостроковій перспективі шияхом зростання продуктивності та ефективності сільськогосподарського виробництва. Таким чином, було запропоновано реалізацію наступних стратегічних завдань: запровадження нової технології, що полягає в постійному моніторингу стада корів, відкриття нової ферми для розширення існуючого ринку та збільшення обсягів виробництва продукції, побудова пелетної котельні з використанням біопалива, а також формування плану навчання персоналу та розробка і реалізація навчальних програм розвитку працівників.

Кдючові слова: стратегія, метод, сільськогосподарське підприємство, стратегічне планування, дорожня карта. 